\title{
Acidic conditions permit effective nodulation of alfalfa by invasion-deficient Rhizobium meliloti exoD mutants
}

\author{
Jason W. Reed ${ }^{1}$ and Graham C. Walker ${ }^{2}$ \\ Department of Biology, Massachusetts Institute of Technology, Cambridge, Massachusetts 02139 USA
}

\begin{abstract}
Rhizobium meliloti exoD mutants are deficient in invasion of alfalfa nodules and, as a consequence, the nodules that exoD strains induce fail to fix nitrogen. These nodules appear to be arrested at the same stage as nodules induced by other exo mutants, which do not make an acidic exopolysaccharide called EPS I, or by ndv mutants, which do not produce a periplasmic cyclic $\beta(1,2)$ glucan. However previous genetic and biochemical evidence suggested that the nodule invasion defect of exoD mutants arose from a biochemical deficiency distinct from those of both EPS I-deficient exo mutants and $n d v$ mutants. In this study, we characterize mutant phenotypes of exoD strains in both free-living and symbiotic states. Nodules induced by exoD mutants are generally small and empty of bacteria, and exhibit the same structural features as nodules induced by other invasion-deficient mutants. Putative incipient infection threads were visible in outer cortical cells of these nodules but not in the plant cells in the interior of the nodule. We show that exoD mutants are sensitive to alkaline conditions, ceasing to grow at elevated $\mathrm{pH}$ in liquid yeast extract cultures and exhibiting decreased viability in alkaline medium. Interestingly, we find that buffering the plant growth medium at slightly acidic $\mathrm{pH}(6.0-6.5)$ restores the ability of exoD mutants to invade alfalfa nodules. exoD mutants are thus alkali sensitive for both free-living and symbiotic phenotypes. This result implies that the nodule invasion defect of exoD mutants arises from their sensitivity to alkaline conditions and, furthermore, that alkaline conditions may obtain in the developing infection thread. The deduced amino acid sequence of ExoD is extremely hydrophobic, suggesting that the protein is membrane associated. We propose models whereby absence of a putative membrane protein might lead to sensitivity to alkaline conditions and consequent arrest of nodule invasion.
\end{abstract}

[Key Words: Alfalfa; Rhizobium meliloti; nodule invasion exoD mutants]

Received June 6, 1991; revised version accepted September 24, 1991.

Bacteria-plant interactions range from the pathogenic, in which bacteria parasitize a plant, to the symbiotic, in which two organisms help each other to survive under otherwise difficult environmental conditions. One of the most extensively studied of such interactions is the symbiosis between the nitrogen-fixing bacterium Rhizobium meliloti and the legume alfalfa, which results in the formation of nodules on the roots of the plant. Nodules are specialized organs whose function in plant metabolism is nitrogen fixation, the reduction of atmospheric nitrogen to ammonia. This nitrogen fixation is carried out by the endosymbiotic Rhizobia, which reside in membraneenclosed compartments inside the plant cells in the interior of the nodule (for review, see Long 1989a,b).

Nodulation is a complex process requiring coordinated developmental responses of both the bacterial and plant

\footnotetext{
1Present address: Plant Biology Laboratory, The Salk Institute San Diego, California 92138 USA.

${ }^{2}$ Corresponding author.
}

partners. Nodule formation is normally induced by the bacterial symbiont, but nodule-like structures can also be induced in the absence of bacteria by a bacterially produced Nod factor (Lerouge et al. 1990; Roche et al. 1991; Truchet et al. 1991) or by exogenous plant hormones or plant hormone antagonists (Long and Cooper 1988; Hirsch et al. 1989). In addition, nodules sometimes appear spontaneously (Truchet et al. 1989), and empty nodules can be induced by invasion-deficient bacterial mutants (see below). Nodules induced by exogenous chemical treatments or by $R$. meliloti mutants that cannot invade nodules are small and round; the meristems of these nodules are broad and diffuse, and the nodules fail to elongate (Finan et al. 1985; Dylan et al. 1986; Leigh et al. 1987; Hirsch et al. 1989; van de Wiel et al. 1990). In contrast, nodules induced by wild-type $R$. meliloti bacteria, or by strains carrying mutations in genes required at later stages in nodulation, have persistent meristems at the tip of the nodule and elongate to a 
greater extent. These observations underscore the importance of bacterial invasion to complete nodule development.

Cells of $R$. meliloti invade developing alfalfa nodules through tubes called infection threads. The bacteria first induce curling of emerging root hairs into structures called shepherd's crooks and then initiate an infection thread starting from within the curl of the shepherd's crook. Infection threads grow down the length of the root hairs into the interior of the root cells, extending eventually to the central zone of the developing nodule where they ramify. The bacteria multiply inside the infection threads and are released from the infection threads into the interior of the plant cells while a plant-derived membrane encloses them in a process resembling endocytosis. The endosymbionts then differentiate into bacteroids and commence fixing nitrogen.

Genetic studies have yielded insights into various aspects of nodulation, including nodule invasion (reviewed in Long $1989 \mathrm{a}, \mathrm{b})$. A number of mutants of $R$. meliloti that are unable to invade alfalfa nodules have been described. Many exo mutants fail to produce an acidic extracellular polysaccharide termed succinoglycan or EPS I (Finan et al. 1985; Leigh et al. 1985; Keller et al. 1988, 1990; Long et al. 1988; Muller et al. 1988) or make an altered form of this exopolysaccharide lacking succinyl modifications (Leigh et al. 1987). These mutants have been identified by their altered fluorescence on agar plates containing the laundry whitener Calcofluor, which binds EPS I (Leigh et al. 1985, 1987; Long et al. 1988). The $n d v$ mutants are defective in synthesis or transport of a periplasmic cyclic $\beta(1,2)$ glucan molecule (Dylan et al. 1986; Geremia et al. 1987; Stanfield et al. 1988). Recently, we described a third class of invasion mutants, in the exoD locus. exoD mutants were first identified by their reduced fluorescence on Calcofluor plates (Leigh et al. 1985) but have an additional defect manifested as poor growth on unbuffered yeast extract plates (Reed and Walker 1991). All of these mutants induce the formation of nodules, but arrest at the nodule invasion stage (Finan et al. 1985; Leigh et al. 1985, 1987; Dylan et al. 1986; Geremia et al. 1987; Dickstein et al. 1988; Keller et al. 1988,1990; Muller et al. 1988; Reed and Walker 1991). Nodules induced by these mutants are small, white, and empty of bacteria. Despite their similar symbiotic phenotypes, however, the exo, $n d v$, and exoD mutants suffer from distinct biochemical defects (Reed and Walker 1991). Moreover, we have reported previously formal genetic experiments establishing that exo $D$ mutants are deficient in nodule invasion because of a deficiency distinct from the deficiency of the other exo mutants (Reed and Walker 1991). Particularly significant was the finding that in contrast to EPS I-deficient exo mutants, exoD mutants were not helped to invade nodules when coinoculated with invasion-competent bacteria. Thus, it appeared that exoD encodes a cell-autonomous function (Reed and Walker 1991).

Various possible mechanisms to account for the nodule invasion defects of these different classes of mutants have been suggested. For example, the exo mutants may fail to produce some signal important in nodulation or they may be susceptible to plant defense responses otherwise masked by EPS I (Leigh et al. 1987; Glazebrook and Walker 1989; Puhler et al. 1991). The ndv mutants might be involved in export of some important component (Stanfield et al. 1988; Dylan et al. 1990). Previously, we suggested that exoD mutants might suffer from a metabolic defect that renders them inviable in the specialized environment of the infection thread, a hypothesis suggested by the finding that exoD strains formed smaller colonies on unbuffered yeast extract plates than did the wild-type strain (Reed and Walker 1991). However, none of these models has been demonstrated unambiguously.

In this paper, we present evidence supporting our previous hypothesis that exoD strains normally suffer from an inability to survive nodule invasion. Moreover, a parallel between the free-living and symbiotic mutant phenotypes of exoD strains may indicate the basis for their apparent failure to survive nodule invasion. Specifically, first, we establish that free-living exoD bacteria exhibit decreased viability under alkaline culture conditions. This phenotype is relieved at more acidic $\mathrm{pH}$. Second, we show that mildly acidic conditions allow exoD bacteria to invade alfalfa nodules. Nodules induced on alfalfa by exoD bacteria in standard nodulation medium appear small and devoid of bacteria or bacteroids, like those induced by other invasion-deficient bacteria. In contrast, nodules induced by exoD bacteria in nodulation medium buffered at slightly acidic $\mathrm{pH}$ contain numerous plant cells filled with bacteroids, and they fix nitrogen. Thus, both the free-living and symbiotic deficiencies of exoD mutants are relieved at acidic $\mathrm{pH}$. This result suggests that the sensitivity of exoD bacteria to alkaline conditions accounts for their nodule invasion defect. Moreover, it hints at the environmental conditions possibly obtained in developing nodules during invasion. In addition, we report the sequence of the exoD gene and propose that it encodes a protein localized to the membrane. Our results suggest models to account for the symbiotic deficiency of exoD strains, and they provide insight into the requirements for alfalfa nodule invasion.

\section{Results \\ Structure of exoD-induced nodules}

Previously, we found that exoD bacteria could curl root hairs and induced small, white nodules on alfalfa. These nodules contained mRMA for just one plant-encoded nodule-specific nodulin and released very few bacteria when crushed (Reed and Walker 1991). In all of these respects, exo $D$-induced nodules resembled nodules induced by other characterized invasion-deficient mutants. To extend this comparison, we have examined sections of nodules induced by an exoD strain by light microscopy. Nodules induced by an exoD strain and by a wild-type strain are shown in Figure 1, A and B. Both exoD- and wild-type-induced nodules have a defined cortex, vascular bundles, and a meristem at the distal end. 

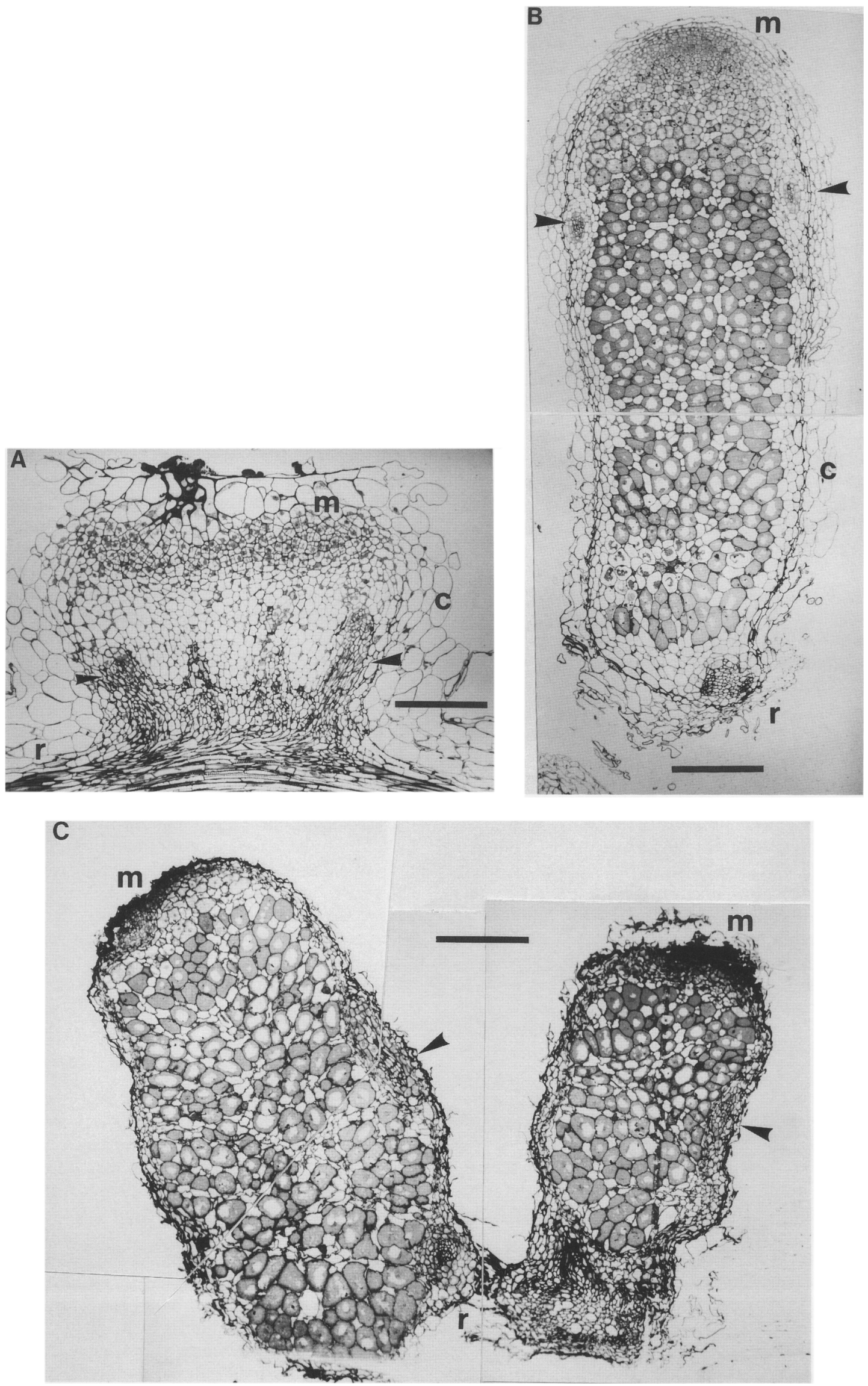

Figure 1. (See facing page for legend.) 
However, the exoD-induced nodule is small and rounded compared with the wild-type nodule and has a broad presumptive meristem extending across the end of the nodule, whereas the wild-type nodule has a small and welldefined meristem. The exoD-induced nodule also has a greater density of vascular tissue than the wild-type nodule. The most striking difference between the two nodules is that the plant cells in the interior of the exoDinduced nodule are devoid of bacteroids, whereas the interior of the wild-type-induced nodule has many cells packed with bacteroids. Thus, the exoD-induced nodule appears nearly identical to previously published micrographs of nodules induced by other exo and $n d v$ mutants (Finan et al. 1985; Dylan et al. 1986; Leigh et al. 1987; van de Wiel et al. 1990).

Two other features of the exoD-induced nodule in Figure 1A are noteworthy. First, several deposits of lightly staining material are present on the outer surface of the cortical cells at the tip of the nodule. Observation of these deposits at higher magnification revealed that they were composed of clumped bacteria (see below). Second, the nodule cortical cells beneath the largest of these deposits are separated, and darkly staining material is visible in the gaps between them. We observed both of these features in sections of three of the four exoD-induced nodules we examined. In no case did this darkly staining material appear to extend beyond the large, loosely packed cells of the nodule cortex.

Several sections from a different exo $D$-induced nodule than that in Figure 1A are shown at higher magnification in Figure 2, A-C. Observation of these sections suggests that the darkly staining material between the cortical cells is contiguous with the clumped bacteria at the surface. In Figure 2A, a clump of bacteria covers the outer surface of a cortical cell. A different section of the same plant cell, shown in Figure 2B, reveals a putative infection thread in the vicinity of the clump of bacteria on the surface of this cell. This structure stains darkly, as do the intercellular spaces and cell walls. Figure $2 \mathrm{C}$ shows a different plant cell penetrated by a cluster of such putative infection threads. In all of these sections, the cell walls appear to be unusually thick. For comparison, an infection thread in the invasion zone of a wild-type nodule is shown in Figure 2D. Bacteria can be seen escaping from this infection thread into the interior of a plant cell. Like the putative infection threads in the exoD-induced nodule, wild-type infection threads frequently occupy intercellular spaces. However, the infection threads in wild-type nodules do not appear to stain as darkly as the putative infection threads in the exoD-induced nodule. Moreover, they tend to be broader than the structures in exoD-induced nodules. Finally, wild-type infection threads are located in the invasion and symbiotic zones of the interior of the nodule, whereas the darkly staining material in exo $D$-induced nodules appears only among the cortical cells at the nodule surface.

We also observed clumped bacteria on the surface of nodules induced by the wild-type strain, and occasionally we noticed darkly staining material between cortical cells (data not shown). However, these features were less prominent than in the exoD-induced nodules, and they appeared only on the surfaces of large cortical cells on the sides of the wild-type nodules, distant from the nodule meristem. [Large cortical cells are not generally present at the tip of growing wild-type nodules at this stage (Fig. 1B).]

\section{Alkaline sensitivity of exoD strains}

Previously, we found that exoD strains formed smaller colonies on agar plates containing $0.5 \%$ yeast extract than did wild-type, exoA, or $n d v B$ strains. We also found that this growth defect of exoD strains could be overcome by including any of several different buffers in the medium (Reed and Walker 1991). This result suggested that exoD strains might be particularly sensitive to extreme $\mathrm{pH}$ and that this sensitivity might account for the inability of exoD mutants to invade nodules (Reed and Walker 1991). Below, we describe experiments showing that the nodulation phenotype of exoD mutants does indeed depend on the $\mathrm{pH}$ of the plant growth medium. We have therefore sought to gain further insight into the basis of the symbiotic defect of exoD mutants by characterizing the growth defect of free-living exoD bacteria in greater detail.

Preliminary experiments with yeast extract plates adjusted to various initial $\mathrm{pH}$ values suggested that exoD mutants were more sensitive than the wild-type strain to alkaline $\mathrm{pH}$ but had no growth defect at acidic $\mathrm{pH}$ (data not shown). In addition, we found that both wild-type and exoD strains growing on yeast extract plates caused the medium to become more alkaline. These observations revealed that exoD mutants are more sensitive than their wild-type parent to alkaline conditions.

We characterized the sensitivity of exoD strains to alkaline $\mathrm{pH}$ with greater precision by testing the effect of alkaline $\mathrm{pH}$ on the ability of the wild-type strain and an exoD mutant to grow in liquid culture. In this experiment a series of tubes containing $0.5 \%$ yeast extract at increasingly alkaline pHs were inoculated with wildtype or exoD17 bacteria, and the cultures were allowed to grow to saturation. At this juncture, we measured the optical density and final $\mathrm{pH}$ of each culture. The data, shown in Table 1, reveal two points: First, the exoD17 strain fails to grow in yeast extract medium at $\mathrm{pH}$ above 8.4 , whereas the wild-type strain grows somewhat in

Figure 1. Sections of nodules induced by wild-type and exoD56 strains in the absence and presence of $30 \mathrm{mM} \mathrm{MES}$ buffer (pH 6.0 ). $(A)$ Section of a nodule induced by an exoD56 strain in the absence of buffer; $(B)$ section of a nodule induced by the wild-type parental strain in the presence of buffer; $(C)$ section of a pair of nodules induced by an exoD56 strain in the presence of buffer. Nodules were harvested 22 days after inoculation. Sections were $0.9 \mu \mathrm{m}$ thick and were stained with Multiple Stain Solution (Polysciences, Warrington, PA). Bars, $200 \mu \mathrm{m}$. $(\mathrm{m})$ Nodule meristem; $(\mathrm{r})$ root; $(\mathrm{c})$ nodule cortex. Arrowheads indicate vascular tissue. 

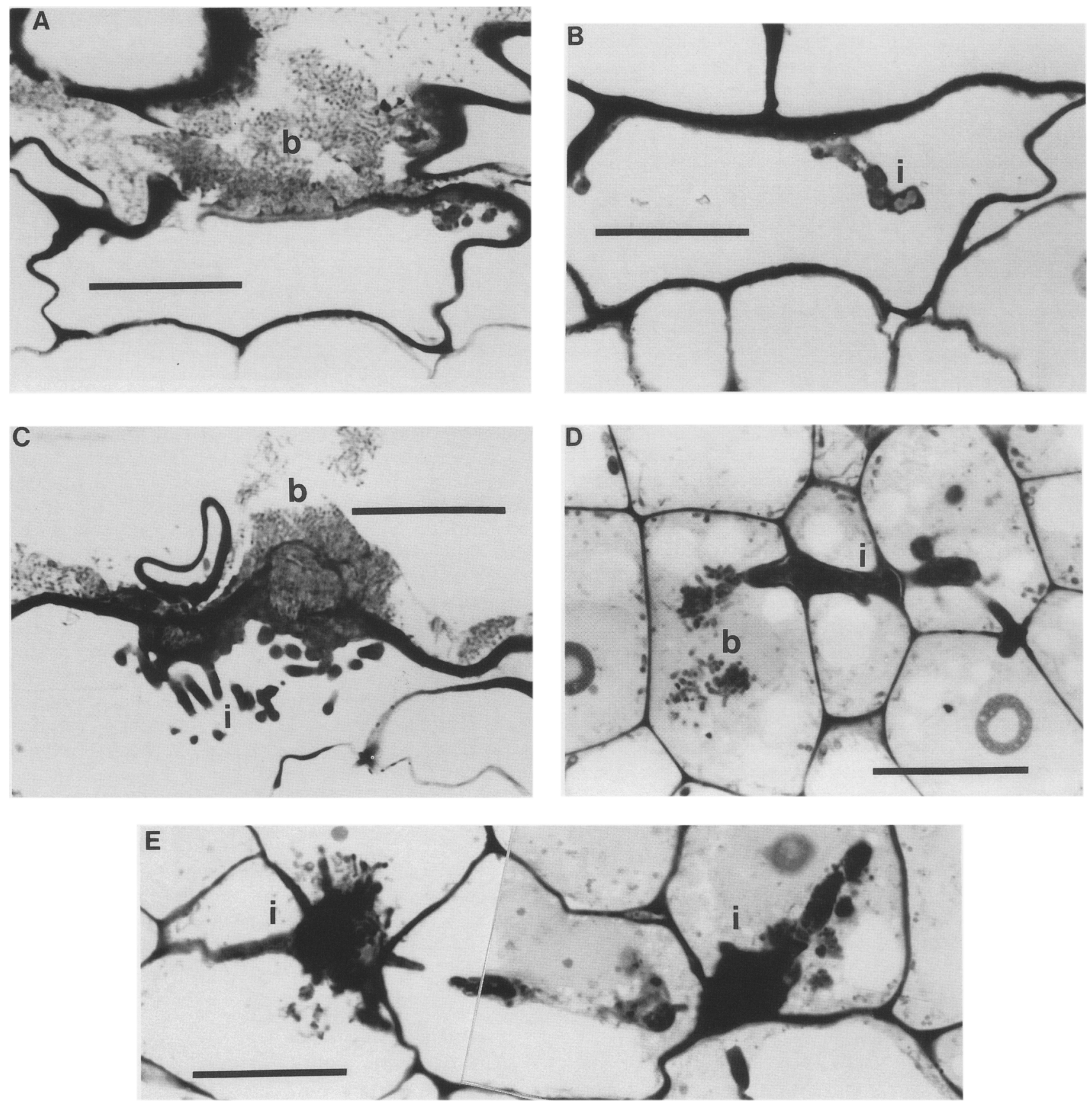

Figure 2. Details of alfalfa nodules induced by exoD and wild-type bacteria. Nodules were harvested 22 days after inoculation. $(A-C)$ Cortical cells of exoD56-induced nodules, showing darkly staining intercellular spaces, clumps of bacteria (b), and putative infection threads (i). $(A, B)$ Different sections of the same plant cell. Parts of the plant cell walls are unusually thick. (D) Infection thread (i) in the invasion zone of the interior of a nodule induced by the wild-type strain $\mathrm{Rm} 1021$. Bacteria (b) released from the infection thread into a plant cell are visible. (E) Rare infection threads (i) in a nodule induced by an exoD17 strain in the presence of MES buffer (pH 6.2). Sections were $0.9 \mu \mathrm{m}$ thick and were stained with Multiple Stain Solution (Polysciences, Warrington, PA). Bars, $20 \mu \mathrm{m}$.

yeast extract medium up to $\mathrm{pH}$ 8.6; second, cultures of either strain that start at a pH below the threshold of alkaline sensitivity alkalinize the medium and reach maximal $\mathrm{OD}_{600}$ when the medium reaches the characteristic limiting $\mathrm{pH}$ for the strain. Consistent with this observation, exoD17 cultures started at a $\mathrm{pH}$ above the characteristic arresting $\mathrm{pH}$ failed to show any increase in optical density. Although the precise $\mathrm{pH}$ of arrest for each strain varied slightly from experiment to experiment, in three separate experiments the exoD17 strain always reached its maximum $\mathrm{OD}_{600}$ at a $\mathrm{pH} 0.1-0.2$ units below that of cultures of the wild-type strain (data 
Table 1. Growth of wild-type and exoD17 strains in liquid $0.5 \%$ yeast extract at alkaline $p H$

\begin{tabular}{|c|c|c|c|c|c|c|c|c|c|}
\hline \multirow[b]{2}{*}{ Strain } & \multirow[b]{2}{*}{ Measurement } & \multicolumn{8}{|c|}{ Medium } \\
\hline & & 1 & 2 & 3 & 4 & 5 & 6 & 7 & 8 \\
\hline None & final $\mathrm{pH}$ & 8.00 & 8.17 & 8.25 & 8.30 & 8.35 & 8.44 & 8.50 & 8.64 \\
\hline $\begin{array}{l}\mathrm{Rm} 1021 \\
\text { (w.t.) }\end{array}$ & $\begin{array}{l}\text { final } \mathrm{pH} \\
\text { final } \mathrm{OD}_{600}\end{array}$ & $\begin{array}{l}8.60 \\
1.77\end{array}$ & $\begin{array}{l}8.61 \\
1.35\end{array}$ & $\begin{array}{l}8.59 \\
1.55\end{array}$ & $\begin{array}{l}8.60 \\
1.32\end{array}$ & $\begin{array}{l}8.59 \\
1.10\end{array}$ & $\begin{array}{l}8.50 \\
0.86\end{array}$ & $\begin{array}{l}8.54 \\
0.67\end{array}$ & $\begin{array}{l}8.64 \\
0.24\end{array}$ \\
\hline $\begin{array}{l}\mathrm{Rm} 7017 \\
(\text { exoD17) }\end{array}$ & $\begin{array}{l}\text { final } \mathrm{pH} \\
\text { final } \mathrm{OD}_{600}\end{array}$ & $\begin{array}{l}8.44 \\
1.37\end{array}$ & $\begin{array}{l}8.38 \\
0.61\end{array}$ & $\begin{array}{l}8.36 \\
0.36\end{array}$ & $\begin{array}{l}8.41 \\
0.38\end{array}$ & $\begin{array}{l}8.41 \\
0.20\end{array}$ & $\begin{array}{l}8.44 \\
0.06\end{array}$ & $\begin{array}{l}8.50 \\
0.05\end{array}$ & $\begin{array}{l}8.60 \\
0.01\end{array}$ \\
\hline
\end{tabular}

Tubes containing $2.5 \mathrm{ml}$ of $0.5 \%$ yeast extract at the indicated $\mathrm{pH}$ were inoculated with $\sim 10^{7}$ cells from cultures grown in $0.5 \%$ yeast extract (pH 7.5 ) and incubated for $40 \mathrm{hr}$ at $30^{\circ} \mathrm{C}$ before measurements were taken. Final $\mathrm{pH}$ of uninoculated medium was measured from an uninoculated control tube incubated in parallel.

not shown). These results suggest that exoD bacteria either cannot grow at a $\mathrm{pH}$ as alkaline as the wild type can or they are more sensitive to killing at alkaline $\mathrm{pH}$ than is the wild-type strain.

To resolve this issue, we assayed the growth rate and the rate of killing of wild-type and exoD17 strains in yeast extract medium buffered at alkaline $\mathrm{pH}$. Growth curves at three different $\mathrm{pH}$ values are shown in Figure 3. At $\mathrm{pH} 7.5$, the wild-type and exoD17 strains grew at similar rates, although the wild-type culture appeared to grow slightly faster than the exoD17 culture. At $\mathrm{pH} 8.1$, the wild-type culture grew significantly before saturating, whereas the corresponding exoD17 culture grew slowly for $\sim 1.5$ doublings and then started to decrease in colony-forming units (cfu). At pH 8.4, the wild-type culture grew a small amount before starting to decrease in colony-forming units, and the exoD17 culture decreased in colony-forming units almost immediately (Fig. 3).

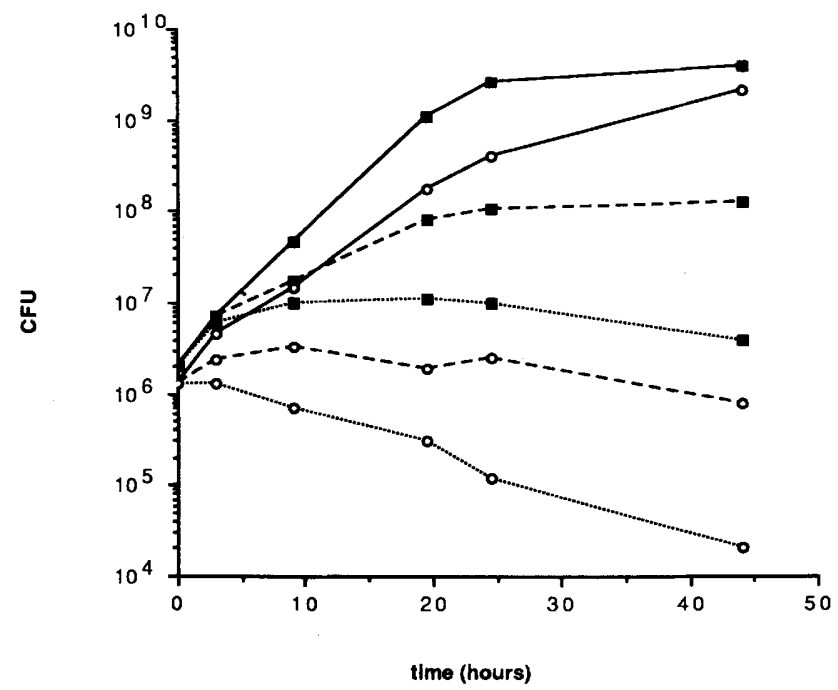

Figure 3. Growth of wild-type and exoD17 strains in $0.5 \%$ yeast extract at different starting $\mathrm{pH}$ values. Cultures were buffered with $50 \mathrm{~mm}$ HEPES ( $\mathrm{pH} 7.5$ ) or $50 \mathrm{~mm}$ tricine (pH 8.1 and 8.4). Colony-forming units (CFU) are plotted against time. (-口-) Rm1021, pH 7.5; (----) RM1021, pH 8.1; (.....) $\mathrm{Rm} 1021, \mathrm{pH} 8.4 ;(--\mathrm{O}-1) \mathrm{Rm} 7017, \mathrm{pH} 7.5 ;(---\mathrm{O}--$-) Rm7071, $\mathrm{pH} 8.1 ;$ (. . . . .) Rm7017, $\mathrm{pH} 8.4$.
These data reveal that both wild-type and exoD17 strains lose viability when placed in increasingly alkaline yeast extract growth medium, precluding accurate measurement of the doubling times of the two strains in this medium. However, it is clear from these data that the defect of the exoD17 strain relative to the wild-type strain is most severe at more alkaline $\mathrm{pH}$.

We tested whether exoD bacteria die more rapidly than wild-type bacteria in alkaline yeast extract medium by measuring survival at $\mathrm{pH} 8.8$, a condition under which we expected neither strain to grow (Table 1). In this experiment, wild-type and exoD17 bacteria were incubated in $0.5 \%$ yeast extract buffered at $\mathrm{pH} 8.8$, and numbers of viable colony-forming units were assayed periodically. As shown in Figure 4A, under these conditions the exoD17 strain had a half-life of 3-4 hr, whereas the wild-type strain had a half-life of 5-6 hr. Although we could not rigorously exclude the possibility that the wild-type strain was growing slightly in this experiment, this result suggests that the impaired growth of the exoD17 strain in alkaline yeast extract medium (Fig. 3) arose at least in part from greater sensitivity to killing by alkaline conditions.

To eliminate possible effects of growth on the apparent survival of the wild-type and exoD17 strains in these alkaline sensitivity experiments, we also measured the survival of the two strains at $\mathrm{pH} 8.8$ in various media lacking a source of carbon. We found that when incubated in $0.85 \%$ saline solution supplemented with 2.5 $\mathrm{mM} \mathrm{MgSO}_{4}, 2.5 \mathrm{mM} \mathrm{CaCl}_{2}$, and $30 \mathrm{~mm} \mathrm{CHES} \mathrm{buffer}(\mathrm{pH}$ 8.8 ), the exoD17 strain had a half-life of $\sim 60 \mathrm{hr}$, whereas the wild-type strain had a half-life of $>100 \mathrm{hr}$ (Fig. 4A). In this same medium at $\mathrm{pH} 7.6$ (buffered with $30 \mathrm{~mm}$ HEPES), each of the two strains had a half-life of $>1$ week (data not shown). Killing curves in two other alkaline solutions are shown in Figure 4B. In water containing only $30 \mathrm{~mm}$ CHES buffer, both strains appeared extremely stable (Fig. 4B). Finally, in $0.85 \%$ saline solution with $30 \mathrm{~mm}$ CHES buffer (pH 8.8), the exoD17 strain had a half-life of 8-9 hr, and the wild-type strain had a halflife of $12-13 \mathrm{hr}$ (Fig. 4B). We have not further pursued the effects of salts on survival of both strains revealed by these results. In any event, under almost all of these conditions the exoD17 strain had a shorter half-life than the wild-type strain. These data therefore confirm that 

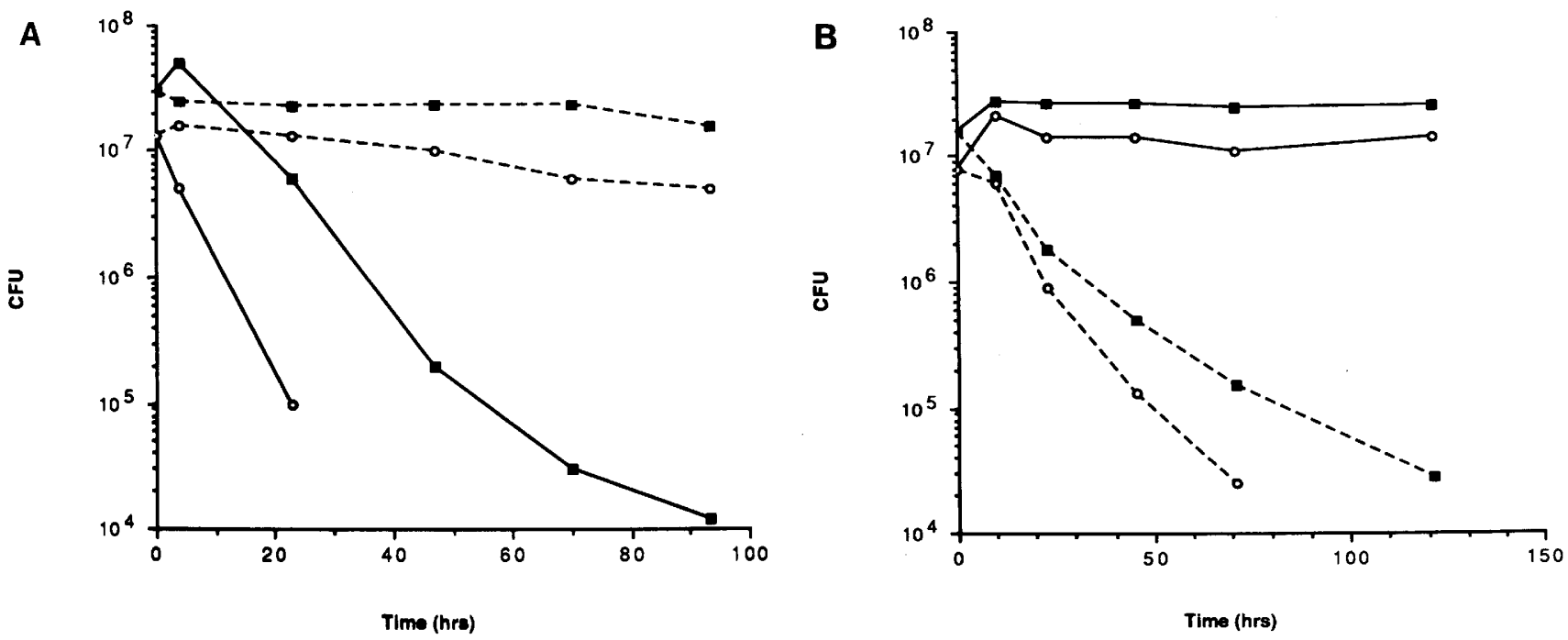

Figure 4. Loss of viability of wild-type and exoD17 strains at $\mathrm{pH} 8.8$. (A) $0.5 \%$ yeast extract (YE) or $0.85 \% \mathrm{NaCl} 2.5 \mathrm{mM} \mathrm{CaCl} 22.5$

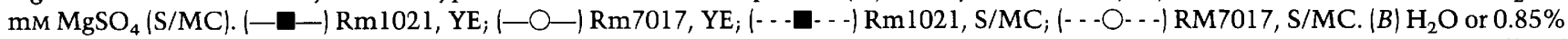
$\mathrm{NaCl}$ (saline). (- - $\mathrm{Rm} 1021, \mathrm{H}_{2} \mathrm{O}$; (-O-) Rm7017, $\mathrm{H}_{2} \mathrm{O}$; (- - - - -) Rm1021, S; (- -O- - - Rm7017, S. All media were buffered with $30 \mathrm{~mm}$ CHES (pH 8.8). Colony-forming units (CFU) are plotted against time.

the exoD strain is more sensitive to killing by alkaline conditions than its wild-type parent.

The decreased viability of exoD strains relative to the wild type suggests that the nodule invasion defect of exoD mutants might conceivably result from increased sensitivity to our standard plant nodulation medium. Thus, exoD bacteria may fail to survive long enough to invade the nodules they induce because they succumb to the medium itself. We tested this model by measuring the survival of wild-type and exoD bacteria in Jensen's nodulation medium at room temperature, conditions mimicking a nodulation experiment. We found that, both on Jensen's agar plates and in liquid Jensen's medium, the exoD bacteria were as viable as the wild-type bacteria (data not shown). exoD bacteria are therefore most likely blocked during nodule invasion, rather than at some earlier stage before invasion commences.

\section{Rescue of nodulation defect of exoD mutants on alfalfa plants}

Our finding that exoD strains were more sensitive to alkaline $\mathrm{pH}$ than the wild type suggested a basis for our previous hypothesis that they might have particular trouble surviving the process of nodule invasion. Specifically, exoD mutants might stall during nodule invasion if at some early stage they encountered an alkaline environment. Therefore, it was possible that the nodulation defect of exoD strains could be alleviated by buffering the Jensen's nodulation medium and the inoculation broth at neutral or acidic $\mathrm{pH}$. To test this idea, we inoculated alfalfa seedlings with wild-type and exoD strains in the presence of buffer.

We found that exoD mutants could indeed be rescued in this way. Alfalfa plants grown on unbuffered medium and inoculated with any of three different exoD strains formed small white nodules containing no bacteroids, as described above (Fig. 1A). In contrast, plants inoculated with exoD bacteria grown on medium buffered with MES ( $\mathrm{pH}$ 6.0-6.5) formed numerous pink nodules in addition to white nodules. Some of these plants became green and grew significantly, rather than turning pale and withering as did control plants grown on unbuffered medium. When crushed, pink nodules from these plants released numerous bacteria, often $>10^{4}$ per nodule. In addition, we found that some of the white nodules from these plants contained as many as $5 \times 10^{4} \mathrm{exoD}$ bacteria, whereas white nodules from plants on unbuffered medium generally released $<20$. To check that the exoD bacteria recovered from the $\mathrm{Fix}^{+}$nodules had not acquired secondary, suppressing mutations that might have allowed them to invade, we reinoculated pools of bacteria recovered from these nodules on alfalfa plants in the absence of buffer. We found that these plants developed only small white nodules and remained short and stunted, establishing that the exoD bacteria that had successfully invaded nodules on the buffered medium had not acquired suppressor mutations.

A section of a pair of pink nodules from a plant inoculated with exoD bacteria in the presence of MES buffer $(\mathrm{pH} 6.0)$ is shown in Figure 1C. Like wild-type-induced nodules (Fig. 1B), these nodules contain plant cells packed with bacteroids (Fig. 1C). However, the rescued exoD-induced nodules appeared less healthy than wildtype-induced nodules. In particular, uninfected plant cells in the symbiotic zone of rescued exoD-induced nodules were less rounded than in nodules invaded by wildtype bacteria, and plant cells in the nodule cortex and parenchyma also appeared small and misshapen (cf. Fig. 1B with C). The flattened appearance of these cells is 
reminiscent of the cells forming the nodule endodermis in wild-type nodules. In addition, the meristem and invasion zone in the rescued exoD nodules were less welldefined than in the wild-type nodule. We sectioned rescued pink nodules from four different exoD-inoculated plants, and found that all of them had these features, except one of these nodules appeared to possess a less abbreviated invasion zone. In this nodule, we observed infection threads. A section of such an infection thread, shown in Figure 2E, appeared similar to a wild-type infection thread except that it stained more darkly and seemed to have rougher, more diffuse edges.

The rescue of exoD strains depended on the $\mathrm{pH}$ at which the Jensen's medium was buffered. As summarized in Table 2, the rescue was most efficient in the presence of MES buffer at $\mathrm{pH} 6.0$ or 6.2 , and slightly less efficient at $\mathrm{pH}$ 6.5. At $\mathrm{pH} 5.7$, growth of the alfalfa plants was stunted even when inoculated with the wild-type $R$. meliloti strain (data not shown). At pH 6.85 and above, exoD strains were not rescued (Table 2). The pH dependence of this effect roughly parallels the $\mathrm{pH}$ dependence of the growth of free-living exoD bacteria, where we found the growth defect relative to the wild-type strain to be most severe at more alkaline $\mathrm{pH}$.

Finally, we confirmed that the rescue of nodule invasion by buffering the nodulation medium was specific to exoD mutants by testing other mutant strains blocked at the same stage in nodulation. Neither an $\operatorname{exo} A$ strain nor an $n d v B$ strain could be rescued by buffering the plates at $\mathrm{pH}$ 6.2. This failure to rescue other strains deficient in nodule invasion reinforces our previous conclusion that exoD strains suffer from a defect distinct from those of the other strains.

\section{Sequencing of exoD}

In the hope of gaining insight into the function of the exoD locus, we decided to sequence it. To delineate the exoD gene further before sequencing, we mutagenized the exoD $D^{+}$plasmid pJWR2 (Reed and Walker 1991) with the transposon $\mathrm{Tn} 3 \mathrm{HoKm}$, which produces operon fusions to the Escherichia coli lacZ gene and confers resis-

Table 2. Proportion of alfalfa plants on buffered nodulation medium with $\mathrm{Fix}^{+}$nodules

\begin{tabular}{lcc}
\hline & \multicolumn{2}{c}{ Inoculated bacteria } \\
\cline { 2 - 3 } $\mathrm{pH}$ of medium & wild type $^{\mathrm{a}}$ & exoD $^{\mathrm{a}}$ \\
\hline 6.0 & $4 / 4$ & $3 / 4$ \\
6.2 & $2 / 2$ & $5 / 6$ \\
6.5 & $4 / 4$ & $2 / 4$ \\
6.85 & $3 / 4$ & $0 / 4$ \\
7.0 & $4 / 4$ & $0 / 4$ \\
8.0 & $0 / 5$ & $0 / 5$ \\
\hline
\end{tabular}

aStrains used were $\mathrm{Rm} 1021$ (wild type), Rm6027 (exoD27), and Rm8503 (exoD56). Buffers were $30 \mathrm{~mm}$ MES (pH 6.0, 6.2, 6.5, or 7.0 ) or $30 \mathrm{~mm}$ HEPES (pH 6.85 or 8.0). Plants were scored as $\mathrm{Fix}^{+}$if they had at least one pink elongated nodule and appeared tall, green, and healthy. tance to kanamycin (Glazebrook and Walker 1989). Insertions that appeared to eliminate complementation of the Calcofluor dim phenotype of the exoD27 mutant were homogenotized into the $\mathrm{Lac}^{-} R$. meliloti strain $\mathrm{Rm} 8501$, and their Calcofluor phenotypes and color on plates containing X-gal were assessed. The data are presented in Figure 5. The insertions causing a dim $(e x o D)$ phenotype on Calcofluor span a $0.6-\mathrm{kb}$ region. All of the insertions expressing $\beta$-galactosidase activity were oriented with the lac $Z$ gene reading from left to right, whereas all insertions oriented with the $l a c Z$ gene reading from right to left did not express $\beta$-galactosidase activity (Fig. 5). Therefore, exoD is probably transcribed from left to right (Fig. 5).

We sequenced the region defined as exoD by the Tn $3 \mathrm{HoKm}$ insertions and found an open reading frame of 240 amino acids in the predicted orientation (Fig. 5). The sequence is presented in Figure 6. A plausible ribosomebinding sequence, GAAGGGAA, appears 5 bases upstream of the third putative initiation codon of this reading frame. The deduced protein sequence starting from this point is 212 amino acids long. A hydrophobicity plot of the putative protein sequence is shown in Figure 7 . The predicted sequence is extremely hydrophobic, with three probable membrane-spanning domains having $>10: 1$ odds of being in the membrane according to the algorithm of Klein et al. (1985) (Fig. 7). Thus, exoD may encode a membrane protein. We found no significant homologies to ExoD in the GenBank protein sequence data base.

\section{Discussion}

The experiments described here show that exoD mutants of $R$. meliloti are sensitive to killing by alkaline conditions but grow at a rate similar to the wild-type parental strain in acidic to neutral medium. In addition, we have found that the nodule invasion defect of exoD strains can be overcome by buffering the nodulation medium at mildly acidic $\mathrm{pH}$. The finding that both wildtype growth rates and nodule invasion by exoD strains depend on maintenance of acidic to neutral $\mathrm{pH}$ suggests, first, that strains carrying Tn5 insertions in the exoD gene are conditional, alkali-sensitive mutants; and second, that exoD strains fail to invade nodules because at some stage in invasion conditions are too alkaline for them to tolerate.

Other nodule invasion mutants of $R$. meliloti have been found to curl root hairs and form incipient infection threads (Dylan et al. 1986, 1990; Leigh et al. 1987; Norris et al. 1988; Reed and Walker 1991). We have found previously that exoD strains are as proficient as the wild type at curling root hairs (Reed and Walker 1991), suggesting that the precise nodulation block of exoD bacteria is probably either in initiation of infection thread growth within the curl of a root hair or in elongation of infection threads. The darkly staining gaps seen between the cortical cells of exoD-induced nodules and the worm-like structures seen in some cortical cells may represent aborted infections. Both structures appear to be 
Figure 5. Map of Tn3HoKm insertions in subclone pJWR2 and phenotypes of homogenotes. Insertions above the line are oriented with the lac $Z$ gene from left to right; those below the line have the lac $Z$ gene from right to left. (Open arrowhead) White on X-gal; (solid arrowhead) blue on X-gal; ( + ) bright Calcofluor; (-) dim on Calcofluor. The arrow indicates the position of the open reading frame deduced by sequencing (see Fig. 6).

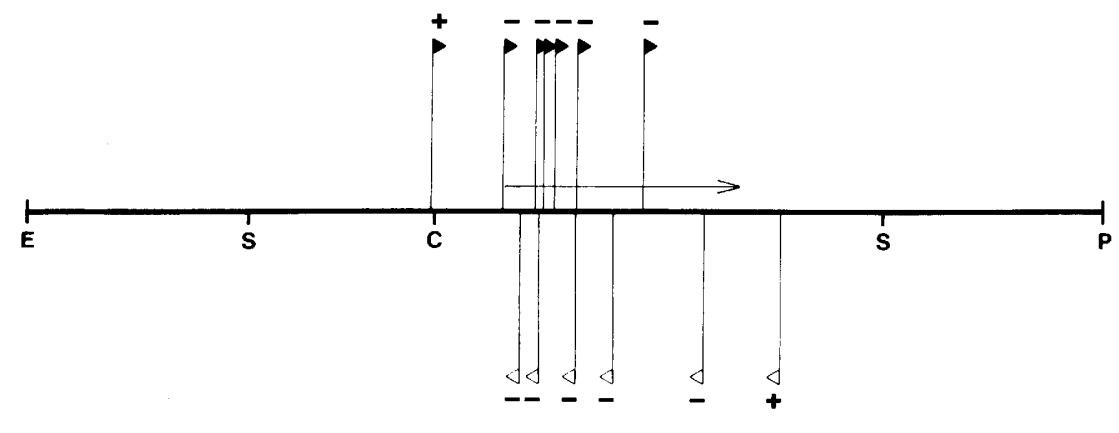

$1 \mathrm{~kb}$ associated with clumps of bacteria on the nodule surface, suggesting that they are induced by bacteria. That these putative infection threads fail to extend beyond the nodule cortical cells suggests that as for other invasion-deficient mutants, the precise symbiotic defect of exoD strains may be in elongation of infection threads. Another possibility is that these darkly staining structures represent an alternative developmental pathway that is followed when normal infection threads fail to form. Invasion of nodules through cracks in the plant surface is known, for example, in nodulation of peanut (Chandler 1978) and Stytosanthes (Chandler et al. 1982), and in stem nodulation of Sesbnia rostrata by Azorhizobium caulinodans (Tsien et al. 1983; Duhoux 1984). In peanut and Stytosanthes, the bacteria infect plant cells from multiple intercellular spaces in the developing nodule, breaching plant cell walls in a manner at least superficially similar to that seen, for example, in Figure $2 \mathrm{C}$ (Chandler 1978; Chandler et al. 1982). Structures similar to those described here have also been seen on alfalfa nodules induced by EPS I-deficient exo nodule invasion mutants (Puhler et al. 1991; A. Hirsch, pers. comm.).

Our ability to rescue the nodule invasion defect of exoD mutants by buffering the medium suggests that early in nodulation the invading bacteria may encounter an environment sufficiently alkaline to kill exoD bacteria. Perhaps the shepherd's crook of the curled root hair encloses an alkaline microenvironment. Alternatively, the matrix of the infection thread may normally be alkaline. In either case, the site where alkaline conditions are toxic to exoD bacteria would have to be accessible to externally supplied buffer. A curled root hair would seem to be more readily accessible to external buffering than the infection thread, which is surrounded by plant tissue for most of its life (Dudley et al. 1987; Vandenbosch et al. 1989|. Coinoculation studies have also suggested that the ability of signal compounds to diffuse into and through the infection thread is limited (Kapp et al. 1990; Reed and Walker 1991). However, some workers have succeeded in rescuing the nodule invasion defect of exopolysaccharide-deficient exo mutants with purified oligosaccharide fragments (Djordjevic et al. 1987; L. Bat- tisti, J.C. Lara, and J.A. Leigh, pers. comm.; A. Urzainqui, D. Ahmann, A. Marra, and G.C. Walker, unpubl.), suggesting that the infection thread is accessible to the medium for at least part of its lifetime. More detailed microscopic studies, for example, using $\mathrm{pH}$ indicators, might address these questions more directly.

It is also possible that in the rescued exoD nodules, buffering at slightly acidic $\mathrm{pH}$ allows invasion through crack entry rather than through infection threads in root hairs (see above). This model might explain the rather disorganized appearance of most of the rescued nodules, if infection of the rescued nodules occurs from multiple sites rather than from within a defined invasion zone as in wild-type alfalfa nodule infection. Again, more detailed microscopy at early stages in nodulation by exoD mutants under acidic conditions might resolve this issue. The finding that exoA and $n d v B$ nodule invasion mutants were not rescued by acidic conditions suggests that both exo and $n d v$ functions are required for invasion whether through infection threads or by some alternative route.

There are several possible reasons that the curl of a root hair or the matrix of an infection thread might be alkaline. The nodulating bacteria might alkalinize their surroundings during invasion, for example, by using as a carbon source some compound whose metabolism causes alkalinization of the medium. Other workers have found that mannitol, metabolism of which causes acidification of the growth medium, can partially help an exoD strain to invade nodules when added to nodulation experiments (C.C. Lee and J.A. Leigh, pers. comm.). These results might therefore hint at the types of energy sources used by the Rhizobia during nodule invasion. In mature bacteroids, dicarboxylic acids are thought to serve as the carbon source (Stowers 1985; Engelke et al. 1987), and R. meliloti strains mutant in dicarboxylic acid transport form Fix ${ }^{-}$nodules. Bacteria in these nodules arrest as bacteroids, however (Bolton et al. 1986; Watson et al. 1988; Engelke et al. 1989; Yarosh et al. 1989); therefore, dicarboxylic acids are unlikely to be an essential carbon source during the earlier process of nodule invasion. Another possibility is that alkalinization of the 
GATTGCGGCAGGAAGA TGAAGGGGCCT"TCTACT'T"ICCTCTATCGGGAGTA TT'GCGGTGCACCA'I'T'TCTGCCGGACC'TCGCCACATTGCTGACCAGAG TAGCTAACGCCGTCCTTCTACTTCCCCGGAAGATGAAAGGAGATAGCCCTCATAACGCCACGTGGTAAAGACGGCCTGGAGCGGTGTAACGACTGGTCTC

101 GGCCCGCTAACCGGAGGTTCATGCGCCTGGCGCTATGGTCTGCCAGGCCCGGTTCGGCGTAAAGAATGCGAGCCGCGGGCACCGCATGGAGCGCCCGCAA CCGGGCGATTGGCCTCCAAGTACGCGGACCGCGATACCAGACGGTCCGGGCCAAGCCGCATTTCTTACGCTCGGCGCCCGTGGCGTACCTCGCGGGCGTT MetvalCysGlnAlaArgPheGlyvalLysAsnAlaSerArgGlyHisArgMetGluArgProgin

201

ACCGT GAAGGGAAAATATGGCGGTCGAGTTCGGCGATTCGCAACGCAGCCTCAGCGACACGCTCACCGGCATGATCGCGTCGATCAGAGGCAACACGA TGGCACTTCCCTTTTTAATACCGCCAGCTCAAGCCGCTAAGCGTTGCGTCGGAGTCGCTGTGCGAGTGGCCGTACTAGCGCAGCTAGTCTCCGTTGTGCT ThrValLysGlyLys I leMetA lavalGluPheGIyAspSerGl nArgSer LeuSerAspThr LeuThrGlyMet IleAlaSer IleArgGiyAsnThrI

TCACGCTGCGCGAGCTGATGATCGAGATCGGCGAGCAGGGCTTCCTCCTTCTCTGCGCGCTGCTGACCCTGCCGTTCCTGATCCCGGTTTCCATTCCGGG AGTGCGACGCGCTCGACTACTAGCT'CTAGCCGCTCGTCCCGAAGGAGGAAGAGACGCGCGACGACT'GGGACGGCAAGGACIAGGGCCAAAGG'IAAGGCCC

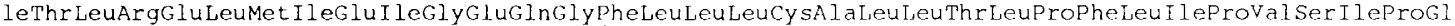

401

CGTCAGCACCG'TCI"TCGGGGCGGCCATCA'I"ICTCA'I"I'CGCT'CGCGATCACCCT'CAATCGCATGCCCTGGCTGCCGAAGCGCATCCTCGACCGGGAGATC GCAGTCGTGGCAGAAGCCCGCCGGTAGTAAGAGIAAAGCGAGCGCTAG'l'GGAGTTAGCGTACGGGACCGACGGCTICGCGTAGGAGCTGGCCCTCTAG

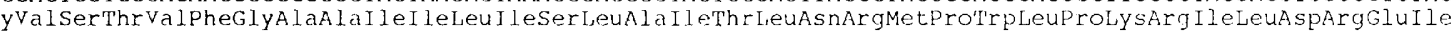

501 GCCACGGAAAAGCTCGTGCCTACGCTCCGAAAAGGTGCGGCACTGGTCTCGAAGCTCGACCGCTATGTGCGCCCGCGGCTCAATTTCCTGACCGAAGGCG CGGTGCCTTTTCGAGCACGGATGCGAGGCTITTCCACGCCGTGACCAGAGCTTCGAGCTGGCGATACACGCGGGCGCCGAGTTAAAGGACTGGCTTCCGC

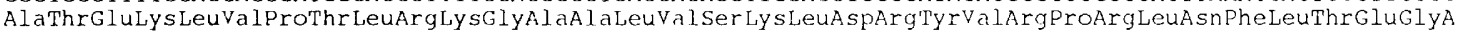

CCCTGATGAACCGTTTCAACGGCCTGATGATCATGGCCGGCGGCGTGCTTCTCATGTTTCCGCTCGGGCTGATTCCGCTGTCGAACACGCTGCCCGGCAT GGGACTACTTGGCAAAGTTGCCGGACTACTAGTACCGGCCGCCGCACGAAGAGTACAAAGGCGAGCCCGACTAAGGCGACAGCTTGTGCGACGGGCCGTA la LeuMetAsnArgPheAsngl y LeuMet I leMetA laGly Gly val Leu LeuMetPheProl euGl y Leu I leProLeuSerAsnThr LeuProGly I

CGCCATCCTGCTCCTGTCGCTCGGCATCATCCAGCGCGACGGGCTGATGGTGGCCGGCGGCTATTTCTTCCTGGTCGCGACCACCGTCTATTTCGCAGTT GCGGTAGGACGAGGACAGCGAGCCGTAGTAGgTCGCGCTGCCCGACTACCACCGGCCGCCGATAAAGAaGGA CCA GCGCTGGTGGCAGA TAAAGCGTCAA

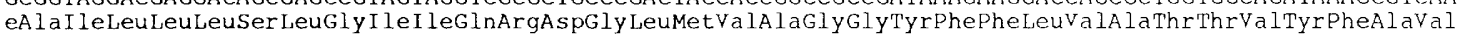

CTCGGCTATGCCGCTTTCGCCGCCGGCCAGGGCCTCTCGCACTTCTTCGTT'TCGTGAT

GAGCCGATACGGCGAAAGCGGCGGCCGGTCCCGGAGAGCGTGAAGAAGCAAAGCACTA

858

LeuGl YTy

Figure 6. DNA sequence of $e x O D$ and deduced amino acid sequence. Shown is the stretch for which sequences of both strands were obtained. The putative exoD openreading frame is shown, with three possible initiation codons. A possible ribosome-binding sequence is boxed.

infection thread matrix is a plant response, perhaps serving to protect the plant against potentially pathogenic bacteria.

The sensitivity of exoD mutants to alkaline $\mathrm{pH}$ could arise from any of a number of primary biochemical defects. For example, exoD mutations might affect the structure of lipopolysaccharide or the fatty acid content of membranes. The nodule invasion defect caused by some exo $D$ mutations is partially suppressed by a mutation altering lipopolysaccharide (Williams et al. 1990; Reed and Walker 1991), and lipopolysaccharide structure can be regulated in response to changes in $\mathrm{pH}$ (Sindhu et al. 1990). Membranes of alkalophilic bacteria have lipid compositions different from neutrophils, for example, having $\mathrm{C}_{40}$ isoprenoid lipids and relatively high concentrations of cardiolipin (Krulwich and Guffanti 1989). exoD mutations might conceivably prevent some adjustment in lipid composition needed under alkaline conditions. Finally, exoD mutants might be deficient in maintaining some type of ionic balance. E. coli strains mutant in a $\mathrm{Na}^{+} / \mathrm{H}^{+}$antiporter are sensitive to alkaline conditions, presumably because they cannot maintain an in- ternal $\mathrm{pH}$ close to neutral by pumping $\mathrm{Na}^{+}$ions out of the cytoplasm in exchange for $\mathrm{H}^{+}$ions (Ishikawa et al. 1987; McMorrow et al. 1989; Padan et al. 1989). However, a gene encoding an $\mathrm{Na}^{+} / \mathrm{H}^{+}$antiporter of $E$. coli has been sequenced (Karpel et al. 1988) and shows no apparent homology to exoD. $\mathrm{A} \mathrm{K}^{+} / \mathrm{H}^{+}$antiporter has also been implicated in $\mathrm{pH}$ homeostasis in alkaline medium for some bacteria (Plack and Rosen 1980; Nakamura et al. 1984; Booth 1985; Krulwich and Guffanti 1989).

The deduced amino acid sequence of the ExoD protein is very hydrophobic and has at least three potential membrane-spanning segments. However, there is no obvious amino-terminal stretch of hydrophobic amino acids that could serve as a signal sequence for protein secretion. These findings are consistent with the hypothesis that the ExoD protein is located in the cytoplasmic membrane (von Heijne 1988; Saier et al. 1989). Several of the phenotypes of exoD strains reported here and in our earlier work could be explained in part by the tentative localization of ExoD to the membrane. For example, altered production of exopolysaccharide could result from 


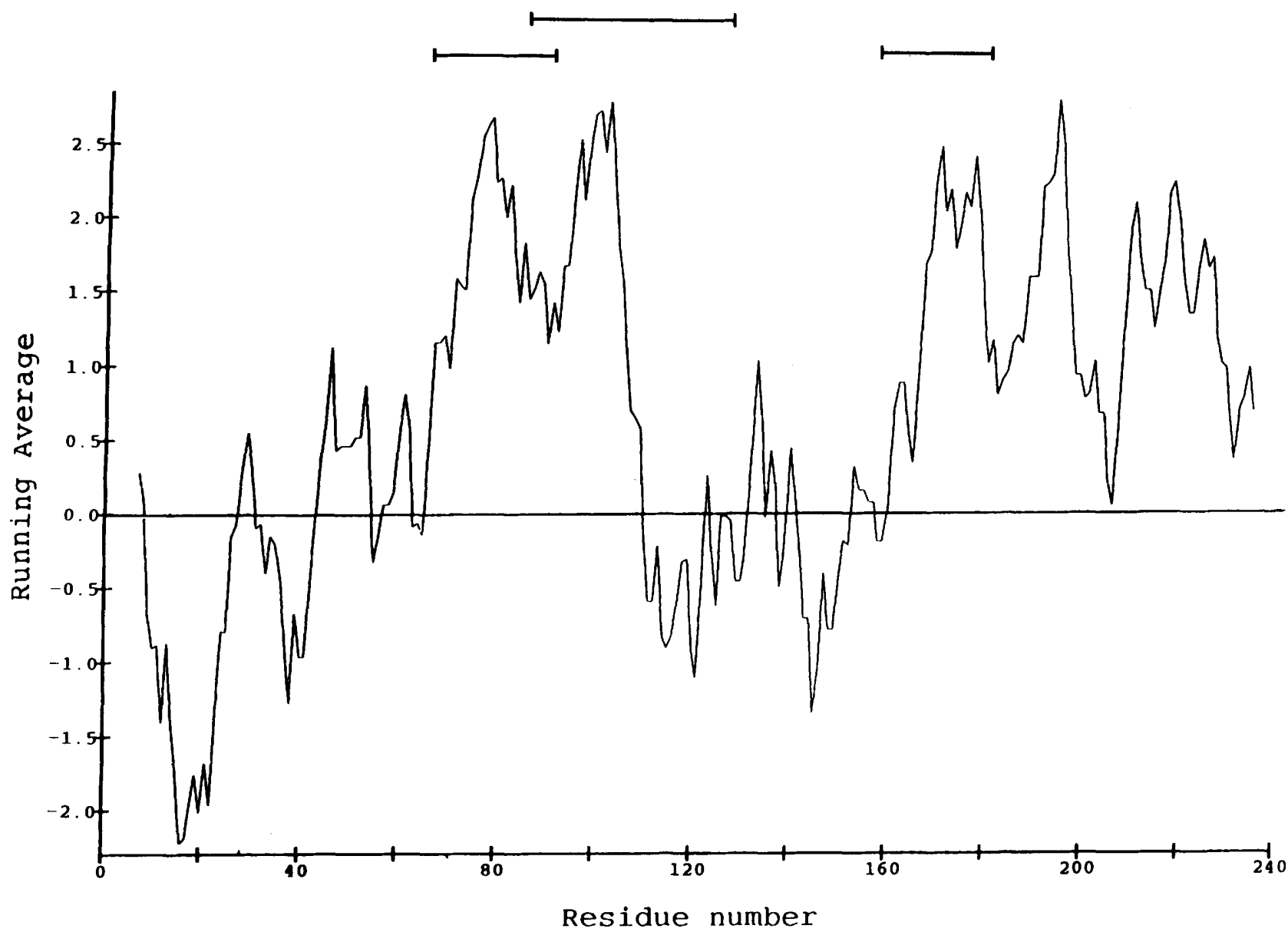

Figure 7. Hydrophobicity plot of ExoD. Hydrophobicity was calculated by the method of Kyte and Doolittle (1982) using a window of 12 amino acid residues. The entire open reading frame is shown. The three most probable potential membrane spanning segments predicted by the ALOM computer program (Klein et al. 1985) are indicated.

perturbation of the inner membrane, where exopolysaccharide synthesis is thought to occur (Sutherland 1985; Shibaev 1986; Jann and Jann 1990|. The inability of exoD strains to be complemented extracellularly in coinoculation assays (Reed and Walker 1991) suggests that the function missing in exoD bacteria is not secreted. The hydrophobic character of ExoD would then more likely indicate that it is membrane bound. Finally, the models invoked above to account for sensitivity of exoD bacteria to alkaline growth medium are consistent with ExoD being localized to a membrane.

Our hypothesis that exoD mutants fail to invade nodules because of sensitivity to alkaline conditions predicts that (1) other $R$. meliloti mutants sensitive to alkaline conditions also will fail to invade nodules, and (2) suppressor mutations that restore the ability of exo $D$ mutants to grow at alkaline $\mathrm{pH}$ also will restore their ability to invade alfalfa nodules. Future genetic experiments will test these two predictions.

\section{Materials and methods}

Strains and media

All strains are derivatives of strain Rm1021 (Meade et al. 1982).
Strains $\mathrm{Rm} 6027, \mathrm{Rm} 7017$, $\mathrm{Rm} 7043$, and $\mathrm{Rm} 8503$ carry, respectively, mutation exoD27::Tn5-233, exoD17:: Tn5, exoD43::Tn5, or exoD56::Tn5 (Leigh et al. 1985; De Vos et al. 1986; Reed and Walker 1991); strain Rm8519 carries mutation ndvB-TY7::Tn5-233 (Dylan et al. 1986; Reed and Walker 1991); and strain Rm7032 carries mutation exoA32::Tn5 (Leigh et al. 1985; Long et al. 1988). Tn 3 HoKm insertions were homogenotized into the $\mathrm{Lac}^{-}$strain $\mathrm{Rm} 8501$ (Glazebrook and Walker 1989). LB medium (Maniatis et al. 1982) was supplemented with $2.5 \mathrm{mM} \mathrm{MgSO}_{4}$ and $2.5 \mathrm{mM} \mathrm{CaCl}_{2}$ (MC). For growth curves, $\mathrm{LB} / \mathrm{MC}$ overnight cultures were subcultured in $0.5 \%$ yeast extract $(\mathrm{pH} 7.5)$ for $3 \mathrm{hr}$ and resuspended in $0.5 \%$ yeast extract buffered at different $\mathrm{pH}$. For killing curves, late log cultures in $\mathrm{LB} / \mathrm{MC}$ medium were pelleted by centrifugation, resuspended in $\mathrm{dH}_{2} \mathrm{O}$ or $0.85 \%$ saline solution and diluted into various buffered media. $\mathrm{pH}$ of yeast extract plates before and after growth of bacteria was estimated with $\mathrm{pH}$ paper. The chromogenic indicator X-gal (5-bromo-4-chloro-3-indolyl-galactoside) was used at $40 \mu \mathrm{g} / \mathrm{ml}$.

Genetic manipulations, plasmid construction, and sequencing

Plasmid pJWR2 contains a 2.9-kb PstI-XmaI fragment containing the exoD gene cloned into the broad host range vector pRK404 (Ditta et al. 1985; Reed and Walker 1991). Transposi- 
tions of Tn3HoKm onto plasmid pJWR2 were obtained and recombined onto the bacterial chromosome, as described previously (Glazebrook and Walker 1989). Plasmid pJWR1 (Reed and Walker 1991) contains the same 2.9-kb PstI-XmaI fragment as pJWR2, in the Bluescript KS + vector (Stratagene, San Diego, CA). For sequencing, plasmid pJWR4 was constructed by inserting a 1.7-kb Sall fragment from pJWR1 into Bluescript KS + . A series of deletions from both ends of plasmid pJWR4 was made with the exonuclease III-mung bean nuclease kit from Stratagene (San Diego, CA). In addition, several deletions were constructed by using convenient restriction sites in plasmid pJWR4. DNA sequencing was done with Sequenase (U.S. Biochemical, Cleveland, $\mathrm{OH}$ ), according to the supplier's instructions. Reactions with both dGTP and dITP were run for each subclone. Both DNA strands were sequenced. The sequence reported here has been submitted to GenBank under accession number M61753.

\section{Plant nodulations and microscopy}

Nodulation of alfalfa (Medicago sativa $\mathrm{cv}$. Iroquois) plants was done on petri plates containing Jensen's agar as described previously (Leigh et al. 1985). Bacteria were recovered from nodules as described previously (Long et al. 1988; Reed and Walker 1991). Buffers were added to both Jensen's medium and the inoculum broth at the same concentration and $\mathrm{pH}$. For microscopy, nodules were harvested 22 days after inoculation, fixed with glutaraldehyde and osmium tetroxide, and embedded in Spurr's resin (Polysciences, Warrington, PA) as described by Hirsch et al. (1983). Sections $(0.9 \mu \mathrm{m})$ were stained with Multiple Stain Solution (Polysciences, Warrington, PA) and viewed by bright-field light microscopy.

\section{Acknowledgments}

We thank G. Barsomian for advice on sequencing, J. Glazebrook for advice on microscopy, P. Reilly for training in use of her microtome and darkroom equipment, C. Holt for use of her microscope, W. Gilbert for running the ALOM protein sequence analysis program, J. Leigh and A. Hirsch for communicating unpublished results, and T.L. Reuber for reading the manuscript. This work was supported by U.S. Public Health Service grant GM31030 to G.C.W. J.W.R. was supported in part by a predoctoral fellowship from the National Science Foundation, and by Merck.

The publication costs of this article were defrayed in part by payment of page charges. This article must therefore be hereby marked "advertisement" in accordance with 18 USC section 1734 solely to indicate this fact.

\section{References}

I. Bolton, E., B. Higgisson, A. Harrington, and F. O'Gara. 1986. Dicarboxylic acid transport in Rhizobium meliloti: Isolation of mutants and cloning of dicarboxylic transport genes. Arch. Microbiol. 144: 142-146.

Booth, I.R. 1985. Regulation of cytoplasmic pH in bacteria. Microbiol. Rev. 49: 359-378.

Chandler, M.R. 1978. Some observations on infection of Arachis hypogaea L. by Rhizobium. J. Exp. Botany 29: 749-755.

Chandler, M.R., R.A. Date, and R. J. Roughley. 1982. Infection and root-nodule development in Stylosanthes species by Rhizobium. J. Exp. Botany 33: 47-57.

De Vos, G.F., G.C. Walker, and E.R. Signer.1986. Genetic manipulations in Rhizobium meliloti using two new transpo- son Tn5 derivatives. Mol. Gen. Genet. 204: 485-491.

Dickstein, R., T. Bisseling, V.M. Reinhold, and F.M. Ausubel. 1988. Expression of nodule-specific genes in alfalfa root nodules blocked at an early stage of development. Genes \& Dev. 2: 677-687.

Ditta, G., T. Schmidhauser, E. Yakobson, P. Lu, X.-W. Liang, D.R. Finlay, D. Guiney, and D.R. Helinski. 1985. Plasmids related to the broad host-range vector, pRK290, useful for gene cloning and for monitoring gene expression. Plasmid 13: $149-153$.

Djordjevic, S.P., H. Chen, M. Batley, J. W. Redmond, and B.G. Rolfe. 1987. Nitrogen fixation ability of exopolysaccharide synthesis mutants of Rhizobium sp. strain NGR234 and Rhizobium trifolii is restored by the addition of homologous exopolysaccharides. J. Bacteriol. 169: 53-60.

Dudley, M.E., T.W. Jacobs, and S.R. Long. 1987. Microscopic studies of cell divisions induced in alfalfa roots by Rhizobium meliloti. Planta 171: 289-301.

Duhoux, E. 1984. Ontogenese des nodules caulinaires du Sesbania rostrata (legumineuses). Can. J. Bot. 62: 982-994.

Dylan, T., L. Ielpi, S. Stanfield, L. Kashyap, C. Douglas, M. Yanofsky, E. Nester, D.R. Helinski, and G. Ditta. 1986. Rhizobium meliloti genes required for nodule development are related to chromosomal virulence genes in Agrobacterium tumefaciens. Proc. Natl. Acad. Sci. 83: 4403-4407.

Dylan, T., P. Nagpal, D.R. Helinski, and G.S. Ditta. 1990. Symbiotic pseudo-revertants of Rhizobium meliloti ndv mutants. J. Bacteriol. 172: 1409-1417.

Engelke, T., M.N. Jagadish, and A. Puhler. 1987. Biochemical and genetical analysis of Rhizobium meliloti mutants defective in $\mathrm{C}_{4}$-dicarboxylate transport. J. Gen. Microbiol. 133: 3019-3029.

Engelke, T., D. Jording, D. Kapp, and A. Puhler. 1989. Identification and sequence analysis of the Rhizobium meliloti $d c t A$ gene encoding the $\mathrm{C}_{4}$-dicarboxylate carrier. J. Bacteriol. 171: 5551-5560.

Finan, T.M., A.M. Hirsch, J.A. Leigh, E. Johansen, G.A. Kuldau, S. Deegan, G.C. Walker, and E.R. Signer. 1985. Symbiotic mutants of Rhizobium meliloti that uncouple plant from bacterial differentiation. Cell 40: 869-877.

Geremia, R.A., S. Cavaignac, A. Zorreguieta, N. Toro, J. Olivares, and R.A. Ugalde. 1987. A Rhizobium meliloti mutant that forms ineffective pseudonodules in alfalfa produces exopolysaccharide but fails to form $\beta(1 \rightarrow 2)$ glucan. J. Bacteriol. 169: $880-884$.

Glazebrook, J. and G.C. Walker. 1989. A novel exopolysaccharide can function in place of the Calcofluor-binding exopolysaccharide in nodulation of alfalfa by Rhizobium meliloti. Cell 56: 661-672.

Hirsch, A.M., M. Bang, and F.M. Ausubel. 1983. Ultrastructure analysis of ineffective nodules formed by nif::Tn 5 mutants of Rhizobium meliloti. I. Bacteriol. 155: 376-380.

Hirsch, A.M., T.V. Bhuvaneswari, J.G. Torrey, and T. Bisseling. 1989. Early nodulin genes are induced in alfalfa root outgrowths elicited by auxin transport inhibitors. Proc. Natl. Acad. Sci. 86: 1244-1248.

Ishikawa, T., H. Hama, M. Tsuda, and T. Tsuchiya. 1987. Isolation and properties of a mutant of Escherichia coli possessing defective $\mathrm{Na}^{+} / \mathrm{H}^{+}$antiporter. I. Biol. Chem. 262: 74437446.

Jann, B. and K. Jann. 1990. Structure and biosynthesis of the capsular antigens of Escherichia coli. Curr. Top. Microbiol. Immunol. 150: 19-42.

Kapp, D., K. Niehaus, J. Quandt, P. Muller, and A. Puhler. 1990. Cooperative action of Rhizobium meliloti nodulation and infection mutants during the process of forming mixed in- 
fected alfalfa nodules. Plant Cell 2: 139-151.

Karpel, R., Y. Olami, D. Taglicht, S. Schuldiner, and E. Padan. 1988. Sequencing of the gene ant which affects the $\mathrm{Na}^{+} / \mathrm{H}^{+}$ antiporter activity in Escherichia coli. J. Biol. Chem. 263: 10408-10414.

Keller, M.P., P. Muller, R. Simon, and A. Puhler. 1988. Rhizobium meliloti genes for exopolysaccharide synthesis and nodule infection located on megaplasmid 2 are actively transcribed during symbiosis. Mol. Plant-Microbe Interactions 1: $267-274$.

Keller, M., W. Arnold, D. Kapp, P. Muller, K. Niehaus, M. Schmidt, J. Quandt, W.M. Weng, and A. Puhler. 1990. Rhizobium meliloti genes involved in exopolysaccharide production and infection of alfalfa nodules. In Pseudomonas: Biotransformations pathogenesis, and evolving biotechnology (ed. S. Silver et al.), pp. 91-97, American Society for Microbiology, Washington, D.C.

Klein, P., M. Kanehisa, and C. DeLisi. 1985. The detection and classification of membrane-spanning proteins. Biochim. Biophys. Acta 815: 468-476.

Krulwich, T.A. and A.A. Guffanti. 1989. Alkalophilic bacteria. Annu. Rev. Microbiol. 43: 435-463.

Kyte, J. and R.F. Doolittle. 1982. A simple method for displaying the hydropathic character of a protein. J. Mol. Biol. 157: 105132.

Leigh, J.A., E.R. Signer, and G.C. Walker. 1985. Exopolysaccharide-deficient mutants of Rhizobium meliloti that form ineffective nodules. Proc. Natl. Acad. Sci. 82: 6231-6235.

Leigh, J.A., J.W. Reed, J.F. Hanks, A.M. Hirsch, and G.C. Walker. 1987. Rhizobium meliloti mutants that fail to succinylate their Calcofluor-binding exopolysaccharide are defective in nodule invasion. Cell 51: 579-587.

Lerouge, P., P. Roche, C. Faucher, F. Maillet, G. Truchet, J.C. Promet, and J. Denarie. 1990. Symbiotic host-specificity of Rhizobium melilotis determined by a sulphated and acylated glucosamine oligosaccharide signal. Nature 344: 781784.

Long, S.R. 1989a. Rhizobium-legume nodulation: Life together in the underground. Cell 56: 203-214.

- 1989b. Rhizobium genetics. Annu. Rev. Genet. 23: 483506.

Long, S.R. and J. Cooper. 1988. Overview of symbiosis. In Molecular genetics of plant-microbe interactions (ed. R. Palacios and D.P.S. Verma), pp. 163-178. APS Press, St. Paul, MN.

Long, S., J.W. Reed, J. Himawan, and G.C. Walker. 1988. Genetic analysis of a cluster of genes required for the synthesis of the Calcofluor-binding exopolysaccharide of Rhizobium meliloti. I. Bacteriol. 170: 4239-4248.

Maniatis, T., E.F. Fritsch, and J. Sambrook. 1982. Molecular cloning: A laboratory manual. Cold Spring Harbor Laboratory, Cold Spring Harbor, New York.

McMorrow, I., H.A. Shuman, D. Sze, D.M. Wilson, and T.H. Wilson. 1989. Sodium/proton antiport is required for growth of Escherichia coli at alkaline pH. Biochim. Biophys. Acta 981:21-26.

Meade, H.M., S.R. Long, G.B. Ruvkun, S.E. Brown, and F.M. Ausubel. 1982. Physical and genetic characterization of symbiotic and auxotrophic mutants of Rhizobium meliloti induced by transposon Tn5 mutagenesis. I. Bacteriol. 149: 114-122.

Muller, P., M. Hynes, D. Kapp, K. Niehaus, and A. Puhler. 1988. Two classes of Rhizobium meliloti infection mutants differ in exopolysaccharide production and in coinoculation properties with nodulation mutants. Mol. Gen. Genet. 211: 1726.
Nakamura, T., H. Tokuda, and T. Unemoto. 1984. $\mathrm{K}^{+} / \mathrm{H}^{+}$antiporter functions as a regulator of cytoplasmic $\mathrm{pH}$ in a marine bacterium, Vibrio alginolyticus. Biochim. Biophys. Acta 776: 330-336.

Norris, J.H., L.A. Macol, and A.M. Hirsch. 1988. Nodulin gene expression in effective alfalfa nodules and in nodules arrested at three different stages of development. Plant Physiol. 88: 321-328.

Padan, E., N. Maisler, D. Taglicht, R. Karpel, and S. Schuldiner. 1989. Deletion of ant in Escherichia coli reveals its function in adaptation to high salinity and an alternative $\mathrm{Na}^{+} / \mathrm{H}^{+}$ antiporter systems. I. Biol. Chem. 264: 20297-20302.

Plack, R.H. Jr. and B.P. Rosen. 1980. Cation/proton antiport systems in Escherichia coli. J. Biol. Chem. 255: 3824-3825.

Puhler, A., W. Arnold, A. Buendia-Claveria, D. Kapp, M. Keller, K. Niehaus, I. Quandt, A. Roxlau, and W.M. Weng. 1991. The role of the Rhizobium meliloti exopolysaccharides EPS I and EPS II in the infection process of alfalfa nodules. In Advances in molecular genetics of plant-microbe interactions, vol. 1 (ed. H. Hennecke and D.P.S. Verma), pp. 189194. Kluwer Academic Publishers, Dordrecht, The Netherlands.

Reed, J.W. and G.C. Walker. 1991. The exoD gene of Rhizobium meliloti encodes a novel function needed in alfalfa nodule invasion. I. Bacteriol. 173: 664-677.

Roche, P., P. Lerouge, J.C. Prome, C. Faucher, J. Vasse, F. Maillet, S. Camut, F. De Billy, J. Denarie, and G. Truchet. 1991. NodRm- 1, a sulphated lipo-oligosaccharide signal of Rhizobium meliloti, elicits hair deformation, cortical cell division, and nodule organogenesis on alfalfa roots. In Advances in molecular genetics of plant-microbe interactions (ed. $\mathrm{H}$. Hennecke and D.P.S. Verma) pp. 119-126. Kluwer Academic Publishers, Dordrecht, The Netherlands.

Saier, M.H. Jr., P.K. Werner, and M. Muller. 1989. Insertion of proteins into bacterial membranes: Mechanism, characteristics, and comparisons with the eukaryotic process. Microbiol. Rev. 53: 333-366.

Shibaev, V.M. 1986. Biosynthesis of bacterial polysaccharide chains composed of repeating units. Adv. Carbohydr. Chem, Biochem. 44: 277-339.

Sindhu, S.S., N.J. Brewin, and E.L. Kannenberg. 1990. Immunochemical analysis of lipopolysaccharides from free-living and endosymbiotic forms of Rhizobium leguminosarum. $J$. Bacteriol. 172: 1804-1813.

Stanfield, S.W., L. Ielpi, D. O'Brochta, D.R. Helinski, and G.S. Ditta. 1988. The ndvA gene product of Rhizobium meliloti is required for $\beta-(1,2)$-glucan production and has homology to the ATP-binding export protein HlyB. I. Bacteriol. 170: 3523-3530.

Stowers, M.D. 1985. Carbon metabolism in Rhizobium species. Annu. Rev. Microbiol. 39: 89-108.

Sutherland, I.W. 1985. Biosynthesis and composition of gramnegative bacterial extracellular and wall polysaccharides. Annu. Rev. Microbiol. 39: 243-270.

Truchet, G., D.G. Barker, S. Camut, F. de Billy, J. Vasse, and T. Huguet. 1989. Alfalfa nodulation in the absence of Rhizobium. Mol. Gen. Genet. 219: 65-68.

Truchet, G., P. Roche, P. Lerouge, J. Vasse, S. Camut, F. de Billy, J.-C. Prome, and J. Denarie. 1991. Sulphated lipo-oligosaccharide signals of Rhizobium meliloti elicit root nodule organogenesis in alfalfa. Nature 391: 670-673.

Tsien, H.C., B.L. Dreyfus, and E.L. Schmidt. 1983. Initial stages in the morphogenesis of nitrogen-fixing stem nodules of Sesbania rostrata. J. Bacteriol. 156: 888-897.

Vandenbosch, K.A., D.J. Bradley, J.P. Knox, S. Perotto, G.W. Butcher, and N.J. Brewin. 1989. Common components of the 
infection thread matrix and the intercellular space identified by immunocytochemical analysis of pea nodules and uninfected roots. $E M B O / .8: 335-342$.

van de Wiel, C., J.H. Norris, B. Bochenek, R. Dickstein, T. Bisseling, and A.M. Hirsch. 1990. Nodulin gene expression and ENOD2 localization in effective, nitrogen-fixing and ineffective, bacteria-free nodules of alfalfa. Plant Cell 2: 10091017.

von Heijne, G. 1988. Transcending the impenetrable: How proteins come to terms with membranes. Biochim. Biophys. Acta 947: 307-333.

Watson, R.J., Y.-K. Chan, R. Wheatcroft, A.-F. Yang, and S. Han. 1988. Rhizobium meliloti genes required for $\mathrm{C}_{4}$-dicarboxylate transport and symbiotic nitrogen fixation are located on a megaplasmid. J. Bacteriol. 170: 927-934.

Williams, M.N.V., R.I. Hollingsworth, S. Klein, and E.R. Signer. 1990. The symbiotic defect of Rhizobium meliloti exopolysaccharide mutants is suppressed by $l p s Z^{+}$, a gene involved in lipopolysaccharide biosynthesis. I. Bacteriol. 172: $2622-2632$.

Yarosh, O.K., T.C. Charles, and T.M. Finan. 1989. Analysis of $\mathrm{C}_{4}$-dicarboxylate transport genes in Rhizobium meliloti. Mol. Microbiol. 3: 813-823. 


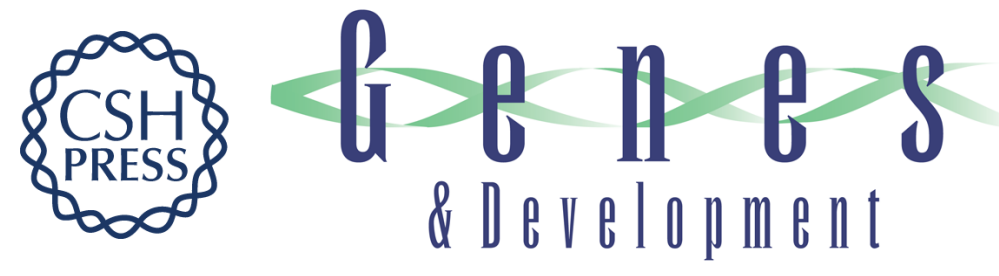

\section{Acidic conditions permit effective nodulation of alfalfa by invasion-deficient Rhizobium meliloti exoD mutants.}

J W Reed and G C Walker

Genes Dev. 1991, 5:

Access the most recent version at doi:10.1101/gad.5.12a.2274

References This article cites 56 articles, 25 of which can be accessed free at:

http://genesdev.cshlp.org/content/5/12a/2274.full.html\#ref-list-1

License

Email Alerting

Service

Receive free email alerts when new articles cite this article - sign up in the box at the top right corner of the article or click here.

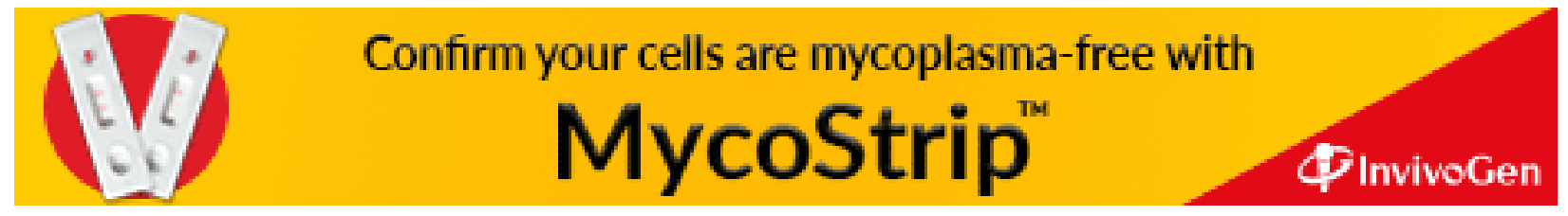

